\title{
BUNGAN BANK DI SULAWESI SELATAN (MUHAMMADIYAH DAN NU)
}

\author{
Fakhruddin Mansyur ${ }^{1}$, Hasanuddin ${ }^{2}$ \\ ${ }^{1}$ Dosen Prodi Hukum Ekonomi Syariah FAl Unismuh Makassar \\ ${ }^{1}$ Dosen Prodi Hukum Ekonomi Syariah FAl Unismuh Makassar
}

\begin{abstract}
Abstrak
Tujuan peneitian ini adalah untuk menggambarkan atau menjelaskan bagaimana pandangan Nahdlatul Ulama (NU) dan Muhammadiyah tentang penerapan hukum bunga bank di sulawesi selatan. metode penelitian yang dimalai dari 1) Rancangan Penelitian, 2) Data Dan Sumber Data, 3) Teknik Pengumpulan Data, 4) Teknis Analisis Data hasil penelitian bahwa NU sulawesi selatan menggunkan bank syariah itu belum sepenuhnya dan belum ada intruksi khusus dari pusat untuk menggunakan bank syariah, hal ini berbeda dari hasil muktamar NU yang sudah jelas-jelas mengharamkan bunga bank itu artinya ini merupakan intruksi khusus kepada kader NU untuk menggunkan bank syariah. sedangkan Muhammadiyah wilayah sulawesi selatan maka disimpulkan bahwa Muhammadiyah sangat memegan teguh putusan yang telah ditetapkan dan setiap amal usaha dan orton harus mengikuti keputusan pimpinan Pusat Muhammadiyah.
\end{abstract}

Kata Kunci: Bunga Bank, NU, Muhammadiyah

\begin{abstract}
The purpose of this study is to describe or explain how the views of Nahdatul Ulama (NU) and Muhammadiyah about the application of bank interest law in south Sulawesi. the research methods are resolved from 1) Research Design, 2) Data and Data Source, 3) Data Collection Technique, 4) Technical Analysis Data research results that NU South Sulawesi used sharia banks is not fully and there is no special instructions from the center to use the bank sharia, this is different from the results of the NU congress that has clearly prohibited the interest of the bank it means this is a special instruction to NU cadres to use Islamic banks. while Muhammadiyah region of south sulawesi it is concluded that Muhammadiyah very memegan teguh decision that has been established and every business and ortonal deed must follow the decision of Muhammadiyah Central leadership.
\end{abstract}

Kay Word: Flower Bank, Nu, Muhammadiyah.

\section{A. PENDAHULUAN}

Kegiatan ekonomi dari masa ke masa terus mengalami perkembangan, yang dahulu ada kini tidak ada, atau sebaliknya.Dulu institusi pemodal seperti bank tidak dikenal dan sekarang ada.Maka persoalan baru dalam fiqh muamalah muncul ketika pengertian riba dihadapkan pada persoalan bank. Di satu pihak, bunga bank (interest bank) terperangkap dalam kriteria riba, di sisi lain, bank mempunyai fungsi sosial yang besar, bahkan dapat dikatakan tanpa bank suatu negara akan hancur. (Muhammad Juhri: 2002)

Tidak dapat dipungkiri lagi bahwa tujuan dari suatu bank adalah mencari keuntungan dan keuntungan 
itu dicapai dengan berniaga kredit. Bank mendapat kredit dari orang luar dengan membayar bunga. Sebaliknya bank memberikan kredit dari kepada orang luar dengan memungut bunga yang lebih besar dari pada yang dibayarkannya. Jadi sedikit penjelasan di atas, maka yang disebut bunga bank adalah tambahan yang harus dibayarkan oleh orang yang berhutang kepada bank atau keuntungan yang diberikan pihak bank kepada orang yang menyimpan uang di bank dengan besar-kecil sesuai dengan ketentuan yang berlaku di bank tersebut. Jadi selisih bunga itulah keuntungan bank. Sehingga bunga merupakan suatu masalah yang tidak dapat dilepaskan dari perusahan bank dunia (umum).

Kasmir (2008 :25) dalam bukunya "bank dan lembaga keuangan lainnya" menjelaskan bahwa yang dimaksud dengan bank adalah perusahaan yang bergerak dalam bidang keuangan, artinya aktivitas selalu berkaitan dalam bidang keuangan.

Ada yang mendefinisikan bank merupakan sebuah lembagakeuangan yang bergerak menghimpun dana dari masyarakat dan kemudian dana tersebut disalurkan kepada yang memerlukan, baik perorangan maupun kelembagaan, dengan sistem bunga.(Djejen Dkk: 1996)

Bunga bank telah menimbulkan pro dan kontra di kalangan umat Islam, khususnya di Indonesia. Muhammadiyah dan Nahdlatul Ulama (NU), dua organisasi Islam terbesar di Indonesia, pada awal tidak menyatakan keharaman bunga bank secara langsung. Muhammadiyah dalam Keputusan Majlis Tarjihnya pada tahun 1968, 1972, 1976 dan 1989, tidak berhasil menetapkan secara tegas keharaman bunga bank. Walaupun menyatakan bahwa bank dengan system riba itu haram, tetapi majelis berpandangan bahwa bunga yang diberikan oleh bank-bank milik negara kepada para nasabahnya atau sebaliknya yang selama ini berlaku termasuk perkara musytabihat (tidak tentu halal-haramnya). Hal ini berkebalikan dengan hasil rapat komisi VI dalam Musyawarah Nasional (Munas) ke-27 Tarjih dan Tajdid Muhammadiyah di Universitas Muhammadiyah Malang (UMM) yang menetapkan bahwa bunga perbankan termasuk riba sehingga diharamkan. Fatwa Muhammadiyah tentang haramnya bunga bank pada Sabtu 3 April 2010 tersebut disambut positif oleh Majelis Ulama Indonesia (MUI), karena MUI 
sudah lebih dulu mengeluarkan hukum haram bunga bank sejak tahun 2003 lalu.

Berbeda dengan MUI dan Muhammadiyah, NU justru menilai bunga bank belum sepenuhnya diharamkan, karena masih ada yang khilaf (beda pendapat) soal penetapan hukum haram itu. Dalam Musyawarah Nasional alim ulama NU pada 1992 di Lampung, para ulama NU tidak memutus hukum bunga bank haram mutlak. Memang ada beberapa ulama yang mengharamkan, tetapi ada juga yang membolehkan karena alasan darurat dan alasan-alasan lain.

Dariatas nampak bahwa kedua organisasi tersebut mempunyai konsep yang berbeda bahkan berseberangan. Namun, keduanya mempunyai sisi kesamaan yaitu demi kemaslahatan umat manusia, meskipun implimentasinya juga berbeda. Perbedaan tersebut terjadi karena adanya sudut pandang yang mempenagruhinya dalam menetapkan hukum tersebut.

Oleh karena itu penyusun tertarik untuk mencoba meneliti dan menelusuri kembali permasalahanpermasalahan hukum bunga bank tersebut menurut pendapat Nahdlatul Ulama melalui Bahsul Masail-nya dan Muhammadiyah dengan Majlis Tarjih- nya, dengan titik tekan pada permasalahan dasar yang melatar belakangi dari perbedaan tersebut mengenai bunga bank adalah melalui metode pengambilan keputasan hukumnya yang diambil dari segi kajian fiqhnya.

Berdasarkan latar belakang masalah di atas, penyusun perlu membatasi rumusan pokok masalah yang diteliti agar mengfokus dan tidak meluas, sehingga menjadi jelas. Bagaimana pandangan Nahdlatul Ulama (NU) dan Muhammadiyah tentang penerapan hukum bunga bank di sulawesi selatan.

Memahami Nahdlatul Ulama (NU) sebagai sebuah organisasi sosial keagamaan, secara komprehensip dan proporsional, maka tidak dapat mengesampingkan aspek-aspek historis (aspek sejarah), yaitu peristiwaperistiwa yang melatar belakangi dan mendorong lahirnya Nahdlatul Ulama.

Gafar Karim (1995 : 47)dalam bukunya "Metamorfosis: NU dan Politisasi Islam Indonesia" Jauh sebelum lahir sebagai organisasi, NU telah ada dalam bentuk komunitas (jama'ah) yang diikat oleh aktivitas sosial keagamaan yang mempunyai karekter Ahlu as-Sunnah Wa alJama'ah.Wujudnya sebagai organisasi 
tidak lain adalah "penegasan formal dari mekanisme informal para ulama sepaham". Arti penting dibentuknya organisasi ini tidak lepas dari konteks waktu itu, terutama berkaitan dengan upaya menjaga eksistensi jama'ah tradisional berhadapan dengan arus paham pembaharuan Islam, yang ketika itu telah terlembagakan, antara lain dalam Muhammadiyah.

Andree Feillard (1995: 9) dalam bukunya "NU vis-à-vis Negara" menjelaskan Perdebatan antara kaum tradisionalis dengan kaum reformis menjadi semakin seru pada tahun dua puluhan. Sehingga dalam beberapa diskusi, termasuk di forum Sarekat Islam (SI), KH. Wahab berhadapan dengan Ahmad Soerkati. Seorang guru besar dari Sudan, Afrika Timur, pendiri gerakan reformasi al-Irsyad. Demikian pula dengan Ahmad Dahlan, seorang pendiri Muhammadiyah.

Ali As'ad (1981 : 91) dalam bukunya "ke-NU-an" menjelaskan pada tahun 1924-an merupakan masa-masa ramainya perdebatan masalah khilafiyah dalam Islam; mengenai bid'ah, mengenai ijtihad, mengenai madzhab dan masalah-masalah fighiyah lainnya. Berkali-kali telah diadakan munazarah (perdebetan sehat) untuk menyelesaikan masalah ini. Di Surabaya, munazarah diikuti oleh para ulama dari berbagai daerah, sebagian di bawah kepimimpinan $\mathrm{KH}$. Abdul Wahab Hasbullah, sebagian di bawah naungan $\mathrm{KH}$. Mas Mansur, dan sebagian lagi dipimpin oleh Sorkati. Dalam munazarah ini Kyai Wahab tetap mempertahankan adanya bermazhab, sementara pihak lain menentangnya dengan gencar, bahkan membid'ah-bid'ahkan masalahmasalah semacam ziarah kubur, sholat tarawih 20 rakaat, pembacaan qunut pada saat sholat shubuh dan lain sebagainya, selalu dipertahankan oleh Kyai Wahab sementara yang lainnya masih tetap menentangnya.

Pada tahun 1911 KH. Ahmad Dahlan mendirikan "Sekolah Muhammadiyah". Dalam sekolah tersebut, dimasukkan pula beberapa pelajaran yang lazim diajarkan di sekolah model Barat, seperti ilmu bumi, ilmu alam, ilmu hayat, dan sebagainya. Begitu pula diperkenalkan cara-cara baru dalam pengajaran ilmu-ilmu keagamaan sehingga lebih menarik dan menyerap.Dengan murid yang tidak begitu banyak, jadilah "Sekolah Muhammadiyah" tersebut sebagai tempat persemaian bibit-bibit pembaharu dalam Islam di Indonesia. 
Dalam Islam sebagai wahana untuk menjembatani dan menyelamatkan ajaran Islam dari adanya pengaruh obyektif yang bersifat internal maupun yang bersifat eksternal bagi perkembangan Islam selanjutnya di Indonesia. Maka pada tanggal 8 Dzulhijjah 1330 yang bertepatan dengan tanggal 18 November 1912 Jam'iyah Muhammadiyah berdiri yang di dalam anggaran dasarnya pertama kalinya bertujuan: "Menyebarkan Pengajaran Kanjeng Nabi Muhammad SAW. kepada penduduk bumi-putera, di dalam residensi Yogyakarta" serta "Memajukan perihal agama Islam kepada sekutusekutunya".

\section{B. METODE PENELITIAN}

Dalam penulisan ini, penulis menggunakan pokok-pokok bahasan secara sistematis yang terdiri dari lima bab dan pada tiap-tiap bab terdiri dari sub-sub sebagai perinciannya.

Sifat dari penelitian ini adalah deskriptif, analitik dan komparatif. (Lexy J. Moleong, 2000:6). Penelitian ini berusaha memaparkan tentang hukum bunga bank secara umum sebelum akhirnya akan mendeskripsikan kerangka pendapat dua organisasi yang diteliti yaitu NU dan Muhammadiyah,
Karena penelitian ini adalah penelitian lapangan, maka pengumpulan data adalah dengan wawancara. Sementara data sekunder diambil dari buku-buku yang dikarang oleh tokohtokoh lain yang dapat mendukung pendalaman dan ketajaman dalam analisis penelitian ini.

Dalam menganalisis dan menginterpretasikan data yang telah terkumpul. Penyusun menggunakan cara berfikir komparasi. Komparasi, yaitu yakni membandingkan sebuah pendapat dengan pendapat yang lain tentang hal yang sama (hukum bunga bank), baik yang memiliki nuansa pemikiran yang hampir sama atau bahkan yang sangat bertentangan (Anton Bakker, dkk.1992:71)

Dalam penelitian ini, Pendapat NU dikomparasikan dengan pendapat Muhammadiyah, sehingga dapat diketahui persamaan maupun perbedaan pendapat keduanya dan dapat ditarik suatu kesimpulan yang konkrit tentang persoalan yang diteliti.

\section{HASIL PENELITIAN}

\section{NU dan Bunga Bank}

Persoalan bank dan bunganya dalam pandangan Nahdlatul Ulama(NU) telahmenjadipersoalanyang signifikan, sehinggaperlu mendapatperhatian yang 
cukupbesar dari paraulama NU. Kaitannya dengan masalah bunga bank, NU melalui forum kajian Bahsul Masailnya telah mengaharamkannya, hal ini dikarenakan bunga bank disamakan dengan gadai yang digunakan pada zaman jahiliyah,jika pemilikbarang gadai tidak bisa membayar uang pada waktunya, maka barang gadaiannya lepas dari pemiliknya dan menjadi milik penggadai dan hal ini telah ditetapkan hokumnya dalam Mu'tamar NUke-2 Tahun 1927 di Surabaya.

Dalam masalahini, terdapat tiga pendapat dari para ahli hokum Islam (jumhur ulama):

Haram:Karenatermasuk barang yang dipungut manfaatnya(rente).

Halal :Sebab tidakada syarat pada waktu akad, sebab menurut para ahli hukum terkenal, bahwa adat yang berlaku itu tidak termasuk menjadi syarat

Syubhat: Tidak tentu halalharamnya.

Sedangkan mu'tamar memutuskan, bahwa yang lebih hati-hati adalah pendapat mu'tamirin yang pertama yakni mengaharamkan adanya bunga dalam dunia perbankan. Sikap NU ini didasari dengan mengambil hujjah dari kitab mu'tabar yaitu:

$$
\text { او امارقلضر شبطر قلعفنر جضففاسد. }
$$

Adapun hokum menitipkan uang dibank, demi keamanan saja, NU menyatakan makruh kalau meyakinkan bahwa uangnya tersebut akan digunakan untuk kegiatan yang melanggar norma-norma agama. Dalam keputusan lain juga telah ditetapkan: "Mengigat bahwa dalam bank, pihak debitur memiliki dan bertanggungjawab penuh atas uang yang dipinjamkan dan bunganya ditentukan atas dasar untung rugi atau besar kecilnya keuntungan dari hasil usahanya, maka transaksi bank tersebut termasuk dalam akad qard dan dengan sendirinya bunga bank termasuk riba qard. Dilihat dari sudut ini bahwa besar kecilnya bunga tergantung pada lama atau sebentarnya tempo pengambilan bunga bank cenderung masuk dalam riba nasi'ah yang berlipat ganda".

Meskipun telah diambil kesepakatan tentang hukum bunga bank, tampaknya para muktamirin masih berbeda pendapat, terutama dalam Munas'Alim Ulamadi Bandar Lampung, 21-25 Januari 1992, khususnya mengenai hokum bunga bank konvensional. Diantaranya sebagai berikut:

Ada pendapat yang mempersamakan antara bunga bank dengan 
riba secara mutlak, sehingga hukumnya adalah haram.

Ada pendapat yang tidak mempersamakan bunga bank dengan riba, sehingga hukumnya adalah boleh.

Ada pendapat yang mengatakan bunga bank hukumya syubhat (tidak identik dengan riba). Meski begitu, Munas memutuskan, pilihan yang lebih berhati-hati adalah bunga bank haram.

Lebihlanjut, NU mengungkapkan bahwa bunga yang diambil oleh penabung di bank adalah riba yang diharamkan. Artinya, apa yang diambil seseorang tanpa melalui usaha perdagangan dan tanpa bersusah payah sebagai tambahan pokok hartanya, maka yang demikian ituter masuk riba. NU kemudian menguatkan pendapatnya, bahwa pengambilan bunga bank oleh nasabah yang menyimpan uangnya dibank adalah haram. Dalam hal ini NU lebih tegas dalam menetapkan keharaman bunga bank yaitu apabila pihak bank menggunakannya untuk perbuatan yang telah dilarang agama.

Dari hasil wawancara pengurus NU sulawesi selatang tentang bunga bank bahwa:

"NU berpendapat bahwa bank konvensional itu sama saja yang membedakan hanya persoalan nama saja didalam bank syariah tetapi memakai cara-cara konvensional ada buganya dan ujung-ujungnya ada ribanya"

Kemudian NU mengemukakan bahwa

" masih ada yang berbeda pendapat tentang bunga bank namun sudah sebagian besar ortom NU sudah menggunakan bank syariah, dan NU masih tergantung dari pribadi masingmasing ingin memakai bank apa saja, karena sejauh ini belum ada intruksi yang mengharuskan untuk memakai bank syariah"

Selanjutnya NU mengemukakan bahwa:
"ortom-ortom NU belum sepenuhnya menggunakan bank syariah NU sebagai induk membawahi ortom-ortom seperti muslimah, ibnu patayat, dan ansor. Itu tergantung masing- masing lembaga tersebut karena belum ada intruksi khusus dari pusat tentang penggunaan bank syariah"

Menurut salah satu Kader NU mengatakan bahwa:

"Bank syariah hanya sebatas nama saja secara realitas prakteknya masih sama bank konvensional yang jadi pembeda hanyalah jumlah ribanya yang lebih sedikit di bank syariah"

Kesimpulan dari pendapat NU bahwa:

" sampai hari juga para ulama masih berbeda pendapat bahwa ada yang melarang, ada yang ditengah-tengah, dan ada yang membolehkan, selagi belum ada hukum yang mengharamkan maka sah-sah saja untuk dilakukan, apalagi dizaman 
sekarang banyak yang membutuhkan peran bank dalam kehidupan sehari-hari maka jika tidak ada solusi lain maka tidak ada larangan untuk melakukanya"

Berdasarkan hasil wawancara

dengan pengurus NU sulawesi selatan maka dapat dipahami bahwa menggunkan bank syariah itu belum sepenuhnya dan belum ada intruksi khusus dari pusat untuk menggunakan bank syariah, hal ini berbeda dari hasil muktamar NU yang sudah jelas-jelas mengharamkan bunga bank itu artinya ini merupakan intruksi khusus kepada kader NU untuk menggunkan bank syariah.

\section{Muhammadiyah dan Bunga Bank}

Dalam buku Himpunan Putusan Majlis Tarjih, (1972: 304-305) menjelaskan bahwa dalam Mu'tamar Majlis Tarjih Muhammadiyah setelah mempelajari:

a. Uraian tentang masalah bunga bank dalam segala seginya yang disampaikan oleh Nandang Komar, Direktur Bank Negara Indonesia Unit 1 Cabang Surabaya.

b. Pembahasan dari para Mu'tamirin Dengan bertawakkal kepada Allah SWT. Menyadari:
1) Bahwa bank dalam sistem ekonomi-pertukaran adalah mempunyai fungsi yang vital dalam perekonomian pada masa sekarang

2) Bahwa bank dalam wujudnya sekarang bukan merupakan lembaga yang lahir dari cita-cita sosial ekonomi Islam.

3) Bunga adalah sendi dari sistem perbankan yang berlaku selama ini.

4) Bahwa umat Islam sebagai umat pada dewasa ini tidak dapat melepaskan diri daripada pengaruh perbankan yang secara langsung atau tidak langsung telah menguasai perekonomian umat Islam.

\section{Mengingat:}

a. Bahwa nash-nash al-Qur'an dan asSunnah dengan jelas mengharamkan riba.

b. Bahwa fungsi bank dalam perekonomian modern sekarang ini bukan hanya menjadi sumber penghasilan bagi bank, melainkan juga berfungsi sebagai alat politik perekonomian Negara untuk kesejahteraan umat (stabilisasi ekonomi).

c. Bahwa adanya undang-undang yang mengatur besar kecilnya bunga 
adalah untuk mencegah kemungkinan terjadinya penghisapan pihak yang kuat terhadap pihak yang lemah di samping untuk melindungi berlangsungnya kehidupan bank itu sendiri.

d. Bahwa hingga saat ini belum ada konsepsi sistem perekonomian yang disusun dan dilaksanakan dengan kaidah Islam.

\section{Menimbang:}

1) Bahwa nas-nas al-Qur'an dan asSunnah tentang haramnya riba mengesankan adanya 'illat terjadinya penghisapan oleh pihak yang kuat terhadap yang lemah.

2) Bahwa perbankan adalah suatu sistem lembaga perekonomian yang belum pernah dialami umat Islam pada masa Rasulullah SAW.

3) Bahwa hasil keuntungan Bankbank milik Negara pada akhirnya akan kembali untuk kemaslahatan umat.

4) Bahwa termasuk atau tidaknya bunga bank ke dalam pengertian riba Syar'i dirasa belum mencapai bentuk yang meyakinka

\section{Memutuskan:}

a) Riba hukumnya haram, dengan nas sarih al-Qur'an dan as-Sunnah.

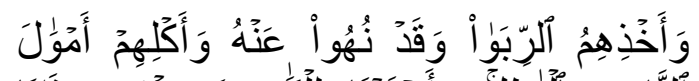

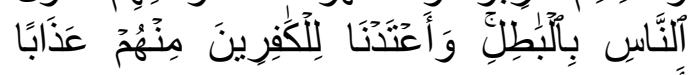
Terjemahnya:

Dan disebabkan mereka memakan riba, padahal Sesungguhnya mereka Telah dilarang daripadanya, dan Karena mereka memakan harta benda orang dengan jalan yang batil. kami Telah menyediakan untuk orang-orang yang kafir di antara mereka itu siksa yang pedih.(Q.S, An-nisa: 161)

b) Bank dengan sistem riba hukumnya haram dan bank tanpa riba hukumnya halal.

c) Bunga bank yang diberikan oleh Bank-bank milik Negara kepada para nasabahnya atau sebaliknya yang selama ini berlaku, termasuk perkara Musytabihat.

d) Menyarankan kepada PP. Muhammadiyah untuk mengusahakan terwujudnya konsepsi sistem perekonomian khususnya lembaga perbankan yang sesuai dengan kaidah Islam.
Dari hasil wawancara dengan pengurus Muhammadiyah wilayah sulawesi selatan dikemukakan bahwa:

"Pandangan Muhammadiyah bank itu sendiri baik itu bank syariah maupun bank konvensional. Jadi, pada Muhammadiyah sendiri ada badan Majelis Tarjih yang kemudian membantu dan 
berfungsi untuk pencerahan dalam memahami agama dan praktek dalam beragama baik untuk pimpinan pusat, wilayah maupun cabang yang membahas persoalan aqidah dan juga muamalah. Nah, dalam hal muamalah itu termasuk didalamnya adalah sistem perekonomian, ini tentu tidak luputdari perhatian badan majelis tajih dan tajdid terkait bank, Muhammadiyah dalam hal ini tidak menanggapi secara personal melaningkan secara kelembagaan fatwanya bersifat kolektif, dan hasil dari pemahaman Muhammadiyah itu sendiri biasanya dihasilkan dari musyawarah (Munas, Musyawarah Tarjih, Musywil tarjih, dan musyawarah daerah tarjih). Terkait bank ini pernah diputuskan /dimusyawarakan pada muktamar majelis tariih, terfokus pada bank konvensional. Perbedaan pemahaman Muhammadiyah terkait bank syariah maupun bank konvensional itu terletak pada penerapanya secara islami, baik dari segi pengumpulan dana ataupun pengaturan dana dan pelayanan dana harus sesuai dengan hukum islam. Prinsipprinsip syariah ini harus dijaga untuknya mUhammadiyah sangat mengapresiasi hadirnya bank syariah karena prinsipprinsip yang digunakan adalah hukum islam, seperti yang kita ketahui bahwa Muhammadiyah ini adalah gerakan islam, berarti amal usahanya harus sesuai islam."

Kemudian ditambahkan tentang diputuskannya bunga bank:
"Terkait bunga bank itu pernah diputuskan pada muktamar ke 27 di Sidoarjo disebutkan terkait status hukum bunga bank dari bank konvensional dan juga koperasi simpan pinjam. Nah dalam bank konvensional secara umum dikatakan hukumnya mustabihaq (perkara yang masih samar-samar) karena terdapat unsur riba walaupun didalamnya terdapat unsur kemaslahatan sehingga dalam putusan itu disampaikan pada muktamar di Malang juga. Putusan Muhammadiyah 1) riba hukumnya haram dengan nash AlQur'an dan as-sunnah itu sudah jelas sekali, 2) bank dengan sistem riba itu hukumnya haram dan bank tanpa riba hukumnya halal 3) bunga yang diberikan oleh bank milik negara terhadap nasabahnya atau sebaliknya yang selama ini berlaku termasuk perkara mustahiq. Jadi jelas, segala sesuatu yang ada riba hukumnya haram, bank apapun itu."

Muhammadiyah selalu memutus-

kan sesuatu dengan musyawarah termasuk hal muamalah (bank yang ada jangkauan muhammadiyah):

"dalam putusan Muhammadiyah berangkat dari pemahaman agama, ketika sudah menjadi putusan maka mutlak bagi warga Muhammadiyah mengamalkan dan mengimplementasikan hasil putusan itu setelah putusan itu hasilnya akan disosialisasikan keseluruh warga Muhammadiyah untuk dipraktekkan atau di implementasikan sehingga itu menjadi upaya-upaya membangun perekonomian yang 
syari karena Muhammadiyah belum punya bank sendiri dan itu salah satu impian juga walaupun sudah ada koperasi simpan pinjam yang sesuai syar'i."

Berdasarkan putusan muktamar mengarahkan dan menyarankan kepada pimpinan pusat Muhammadiyah untuk mengupayakan, mengusahakan terwujudnya konsep syar'i dalam sistem perekonomian khususnya dilembaga perbankan syariah (sesuai dengan kaidah islam) sehingga diharapkan amal usaha menggunakan bank syariah, baik itu penyimpanan dana maupun dalam hal pengambilan dana dan jasa bank dengan bank syariah"

Selanjutnya Muhammadiyah sangat menjunjung tinggi hasil putusan:

"Putusan tarji dan prinsip Muhammadiyah adalah konsisten terhadap putusanputusan itu, sehingga dapat diyakini semua ortom Muhammadiyah Menggunakan bank yang menggunkan konsep syariah"

Berdasrkan hasil wawancara

dengan pengurus Muhammadiyah

wilayah sulawesi selatan maka

disimpulkan bahwa Muhammadiyah sangat memegan teguh putusan yang telah ditetapkan dan setiap amal usaha dan orton harus mengikuti keputusan pimpinan Pusat Muhammadiyah.

\section{KESIMPULAN}

Keduan organisasi Islam ini antara NU dan Muhammadiyah samasama telah mengeluarkan Fatwa tentang keharaman bunga bank yang dipersamakan dengan riba, sehingga kedua organisasi besar ini menyerukan untuk menggunakan bank yang sesuai dengan konsep syariah, hal ini bank yang sesuai dengan konsep keuangan dalam islam adalah bank syariah. dalam penerapan fatwanya di daerah sulawesi selatan masih ada perbedaan antara NU dan Muhammadiyah yakni pada penggunaan bank, jika NU masih sebagian ortomnya yang menggunkan bank syariah berbeda dengan Muhammadiyah yang mengupakan semua amal usaha dan ortom menggunakan bank syariah.

\section{DAFTAR PUSTAKA}

Al-qur,an dan terjemahannya "lajnah pentashih mushaf alqur,an"(departemenagama republik indonesia)

Ahmad Sukarja. "Riba bunga bank" 1995 A. Wahid Jaini "dunia pemikiran kaum santri (Yogyakarta : LKPSM :)

Anwar Ahmad Ashar Basyir, Hukum Islam tentang Riba , Utang-piutang, Gadai, (Bandung: PT. Al-Ma'arif,1983) 
Nasution, Tinjauan Ekonomi atas dampak Paket regulasi tahun 1988 pada sistem Keuangan Indonesia PAU Ekonomi -UI PT Gramedia 199

Antonio, M. Syafe,i. 2001. Bank syariah : dari teorike praktek. Gema Insani Pres.

Arif salams Abdul,1968 ilmu ushul fiqh, Kairo: Dar-al kuwaitiyyah.

Abbas anwar , 2003 hukum bungan bank konfensional, pengurus pusat Muhammadiyah

Dahlan siamat, manajemen lembaga keuangan, intermedia 1995

Djamil , Faturrahman. 1995.Metode Majelis Tarjih Muhammadiyah.Jakarta Logos Publishing House

Djejen DKK.1996 “Fiqh” Semarang: Toha Putra

Huosen Ibrahim 1990 "kajian tentang bunga bank menurut hukum islam". Paper di presentasikan pada worshop on bank and banking insterest, disponsori oleh majlis ulama indoesian, safari garden hotel, cisarua, bogor

Hendi Suhendi, M.Si 1997 “fiqh muamalah” Jakarta : PT Raja Grafindo Persada

Hajar Ibnu Al- Asqalani 2001 "bulugul Al-maram"Surabaya Al- Hidayah

Muhammad 2008 “meteodologi penelitian ekonomi islam” Jakarta : PT Raja Grafindo Persada

Mansur, Kahar. 1990, beberapa pendapat tentang riba .Jakarta : Kalam Mulia "Pedoman Hidup Islami Warga Muhammadiyah".jakarta: suara muhammadiyah

Muhammad Zuhri 1996 "Riba dalam al-Qur'an dan Masalah Perbankan: sebuah Tilikan Antisipatif”Jakarta: Raja Grafindo,

Soekamti soejono 1980 "pokok-pokok sosiologi hokum" Rajawali press

Syihab Muhammad Quraisy.2003 "membumikan Al-Qur,an: fungsih dan peranwahyu dalam kehidupan masyarakat" bandung : Al-ma,arif.

Sabiq, Sayyid. 1996. Fikih Sunnah, alih bahasa Kamaluddin A. Marzuki. Bandung: PT. Al-Ma'arif.

Yasin As,ad. 1996 "fatwa-fatwa kontenporer" Jakarta: Gema Insane Prees.

Zaini Wahid.1996 "dunia pemikiran kaum santri’Yogyakarta: LPKSM

Zuhri Muhammad 1996 "riba dalam al-Qur'an dan masalah dalam perbankan: sebuah tilikan antisipatif” Jakarta: Raja Grafindo 